\title{
Commiphora leptophloeos Phytochemical and Antimicrobial Characterization
}

\author{
Jorge J. de Souza Pereira1,2†, Aline de P. C. Pereira ${ }^{3 t}$, Jannyson J. B. Jandú ${ }^{3}$, \\ Josinete A. da Paz ${ }^{4}$, Sergio Crovella ${ }^{1,2}$, Maria T. dos Santos Correia ${ }^{3}$ and \\ Jaqueline de Azevêdo Silva ${ }^{1,2 *}$
}

'Department of Genetics, Federal University of Pernambuco, Recife, Brazil, ${ }^{2}$ Laboratory of Immunopathology Keizo Asami, Federal University of Pernambuco, Recife, Brazil, ${ }^{3}$ Laboratory of Glycoproteins, Department of Biochemistry, Federal University of Pernambuco, Recife, Brazil, ${ }^{4}$ Department of Fundamental Chemistry, Federal University of Pernambuco, Recife, Brazil

Commiphora leptophloeos is a plant specie usually known for its medicinal purposes in local communities in Northeast Brazil. In order to evaluate its therapeutic potential, we aimed to determine the phytochemical and antimicrobial properties of $C$. leptophloeos extracts. Thin Layer Chromatography (TLC) was able to detect the presence of phenolic compounds, flavonoids and reducing sugars. Three phenolic compounds were identified by HPLC and described as Gallic, Chlorogenic and Protocatechuic acids. On the other hand, $\mathrm{H}^{1} \mathrm{NMR}$ analysis revealed the presence of hinokinin, a bioactive lignan further characterized in the present work. The minimum inhibitory concentration (MIC) values for hinokinin ranged from 0.0485 to $3.125 \mathrm{mg} / \mathrm{mL}$ in different $S$. aureus clinical isolates and showed a bactericidal activity against MRSA isolated from blood (MMC $0.40 \mathrm{mg} / \mathrm{mL}$ ) and postoperative secretion ( $\mathrm{MMC}=3.125 \mathrm{mg} / \mathrm{mL})$. C. leptophloeos extracts also showed antimicrobial activity against Mycobacterium species such as M. smegmatis ( $\mathrm{MIC}=12.5 \mathrm{mg} / \mathrm{mL}$ ) and $M$. tuberculosis ( $\mathrm{MIC}=52 \mathrm{mg} / \mathrm{mL}$ ). Additionally, we determined the toxicity of $C$. leptophloeos by in vitro $\mathrm{HC}_{50}$ tests with hemolytic activity detected of $313 \pm 0.5 \mu \mathrm{g} / \mathrm{mL}$. Our results showed that C. leptophloeos possesses inhibitory properties against MRSA as well as several other clinically important microorganisms. Furthermore, the present work is the first report of the presence of hinokinin in Commiphora genus.

Keywords: plant-derived products, drug discovery, antibacterial agents, multidrug resistance, hinokinin, Mycobacterium tuberculosis, S. aureus

\section{INTRODUCTION}

The discovery of antibacterial agents was a breakthrough event in medicine and represented a landmark in human health. However, the widespread misuse of these agents has brought to light two major problems involving the treatment of bacterial infections: (i) the emergence of Multidrug-resistance Organisms (MDROs) and (ii) the existence of bacteria innately resistant to most antibiotics. The rising number of MDROs is an imminent threat worldwide, especially the Methicillin-resistant Staphylococcus aureus (MRSA), which has acquired a gene involved in the resistance to all available $\beta$-lactam antibiotics. In this scenario, Tuberculosis (TB), a disease caused 
by Mycobacterium tuberculosis, has co-evolved along with humans and remains as a public health issue to date. In 2015, TB was regarded as the world's deadliest infectious disease (WHO, 2015), as 1 million children under 14 years old fell ill, 140.000 children died and over 53 million otherwise healthy children carried the TB bacillus. Moreover, TB is the leading cause of deaths by HIV-positive individuals as, in 2015, 1 in 3 HIV deceases was linked to TB infection. In the context of multidrug-resistance, approximately 480000 people developed multidrug-resistant TB (MDR-TB) worldwide and the major causes are inappropriate treatment, misuse of drugs or use of poor quality medicines (Venturini et al., 2014; WHO, 2015).

The natural products found in medicinal plants are a promising source for new antibacterial compounds (Lawn et al., 2013; Zumla et al., 2013). Plant-derived antimicrobial compounds belong to an exceptionally wide diversity of classes, including terpenoids (Bhalodia et al., 2011), lignans (Teponno et al., 2016), alkaloids and peptides (Bhatter et al., 2016), phenolic compounds (Heleno et al., 2015) and coumarins (Bhatter et al., 2015, 2016). All of the aforementioned compounds are regarded as secondary metabolism products in plants, not strictly required for their survival, but usually conferring a positive effect for its use as medicinal purposes (Harborne, 1997; Kroymann, 2011).

Commiphora leptophloeos, usually known as Imburana of Sertão, belongs to the Burseraceae family, which includes trees and shrubs from tropical and subtropical regions, and is traditionally used by indigenous tribes as an infusion, tea or syrup for the treatment of their illness, such as infectious and inflammatory ones (Bennett and Prance, 2000; Silva et al., 2011). The Commiphora genus comprises over 150 species most of which are confined to Eastern Africa and are usually applied in traditional medicine (Abdel-Daim et al., 2015). In Brazil, it is found where the vegetation is exposed to adverse climate and soil conditions, typical of the Sertão physiognomy, a semi-arid region in Northeast Brazil characterized by a very dry and extremely hot weather throughout the year with low rainfall rates (Peña-Claros et al., 2012).

Therefore, plant species from Caatinga ecosystems, can become promising targets in the searches for new active substances. The aim of the present study included characterization of $C$. leptophloeos extracts, isolation of biomolecules and fractions with antimicrobial activity, and analysis of possible toxic effect in human blood cells.

\section{MATERIALS AND METHODS}

\section{Biological Material (Plant)}

The stem bark of C. leptophloeos was collected at Parque Nacional do Catimbau, Pernambuco - Brazil. The authors confirm that the named authority Instituto Chico Mendes de Conservação da Biodiversidade granted permission (SISBIO 16806) for our described field searches. The botanical identification and the deposition of plant specimens were performed at the Herbarium of the Institute of Agricultural Research of Pernambuco (IPA-PE) (IPA n $\left.{ }^{\circ} 84037\right)$.

\section{Preparation of the Extracts}

The dried bark (25 g) of C. leptophloeos was obtained by saturation in order of increasing polarity: submitted to Cyclohexane (CLCHE), Chloroform (CLCLE), Ethyl Acetate (CLAEE), Methanolic (CLMEE), and Aqueous (CLAQE) $(250 \mathrm{~mL})$ by agitation at 180 rotations per minute (rpm). After $24 \mathrm{~h}$, the extract was filtered (Whatman ${ }^{\circledR}$ number 2) and concentrated at $45^{\circ} \mathrm{C}$ under vacuum in a rotary evaporator (Concentrator 5301, Eppendor $\mathrm{f}^{\circledR}$ ). The powder produced was kept at $-20^{\circ} \mathrm{C}$ for future use. For phytochemical and antimicrobial analysis, the extracts were dissolved in your respective solvents at the concentration of $100 \mathrm{mg} / \mathrm{mL}$ for all biological assays.

\section{Phytochemical Analysis}

Determination of Phenolic Acid Compounds by HPLC

For the determination of phenolic acids, the extract powder $(0.5 \mathrm{~g})$ was diluted in methanol: water $(20 \%, \mathrm{v} / \mathrm{v})$ at ultrasonic bath sonicator for $30 \mathrm{~min}$. Then, the extracts were filtered and passed through a SPE C18 cartridge with the following solvents: acetone, trichloroacetic acid, water $(4 \%, \mathrm{v} / \mathrm{v})$ and methanol. Samples were later submitted to a rotary evaporator (Concentrator 5301, Eppendorf ${ }^{\circledR}$ ) and re-suspended in methanol. The qualitative analysis of phenolic content for each extract was performed by UFLC (Ultra-Fast Liquid Chromatographic - LC20AD, Shimadzu). Separations were conducted on a XR ODS, $50 \mu \mathrm{m} \times 3.0 \mu \mathrm{m} \times 2.2 \mu \mathrm{m}$ column . The elution was performed with water: acetonitrile: methanol: ethyl acetate: glacial acetic acid (86:6:1:3:1, respectively). The column temperature was set to $40^{\circ} \mathrm{C}$ and the flow rate was $0.4 \mathrm{~mL} /$ minute for $5 \mathrm{~min}$. Prior to injection, sample extracts $(200 \mu \mathrm{L})$ were filtered with PTFE syringe $0.22 \mu \mathrm{m}$ filters (Phenomenex, UK). Phenolics in each bark extract were identified by comparison of their retention times with corresponding standards and by their UV spectra obtained with the diode array detector - DAD (SPDM20A). Gallic acid, vanillic acid, protocatechuic acid, chlorogenic acid, coumaric acid, ferulic acid, quercetin, and rutin were used as standard compounds (Prieto et al., 1999; Fernandes et al., 2011; Gómez-Caravaca et al., 2013). The linear regression equation for each standard curve was obtained by plotting the amount of standard compound injected against the peak area.

\section{Qualitative Phytochemical Analysis by TLC}

An aliquot of $100 \mu \mathrm{L}$ of each C. leptophloeos extract was subjected to qualitative phytochemical analysis to ascertain the presence of secondary metabolites such as: coumarins (Gocan and Cimpan, 2007), flavonoids (Garcia et al., 1993), tannins and phytosteroids (Pascual et al., 2008), reducing sugars (Krishnamurthy et al., 2012), and saponins (Ng et al., 1994), respectively. The classes of compounds were visualized using Thin Layer Chromatography (TLC) on silica gel 60 F254 (Merck, Germany), and different systems of development and adequate visualization techniques were used as: Dragendorff test, NEU-PEG, KOH-Ethanol, Acetic Anhydride test, Vanillin-sulfuric acid, Quercetin, Tannic acid, Benzopyrone equivalent, according to the respective method of elucidation. 


\section{Determination of Total Phenol Content}

The total amount of phenolic compounds from the extracts was determined according to the Folin-Ciocalteu procedure with in house modifications (Singleton et al., 1965). Briefly, samples $(200 \mu \mathrm{L})$ were introduced into test tubes with $1.0 \mathrm{~mL}$ of Folin-Ciocalteu reagent $(1: 1 \mathrm{v} / \mathrm{v})$ and $2.5 \mathrm{~mL}$ of sodium carbonate $(20 \%)$. The mixture was incubated for $30 \mathrm{~min}$ at room temperature and allowed to stand still for additional $30 \mathrm{~min}$. The absorbance from the blue colored mixture was measured at $765 \mathrm{~nm}$ (Gene Quant 1300, GE Healthcare). The amount of total phenol was calculated as milligrams (mg) of Gallic Acid Equivalents (GAE)/g of dry mass from calibration curve of Gallic acid standard solution. For the Gallic acid, the curve absorbance versus concentration is described by the equation $y=1.5221 \mathrm{x}+$ $0.0081\left(r^{2}=0.9712\right)$.

\section{Chromatographic Analysis by Flash and CCD Chromatography}

Based on the initial phytochemical results and visualization of the presence of phytosteroids and lignans in qualitative tests, the 0.8 g yield CLCLE was then submitted to Flash Chromatography (Clark et al., 1978; Still, 2002) using silica gel 60 F254 (Merck, Germany) as the stationary phase and $\mathrm{CHCl}_{3} / \mathrm{MeoH}$ (99.1) as the mobile phase. From this experiment, 45 fractions with $15 \mathrm{~mL}$ each were obtained. The fractions were submitted to Thin Layer Chromatography (TLC) in different groups depending on their chromatography patterns and similarity as follows: F1-F8, F9, F10-F14, F15-19, F20-26, F27-F28, F29-F38, F39-F42 e F44F45. The fraction F9, which yielded $0.06 \mathrm{~g}$ was once submitted to silica gel column chromatography and 100 new fractions were obtained and analyzed following the data from Cambridge Crystallographic Data Centre (CCDC). Among all fractions, F16 was the purest one and was the submitted to ${ }^{1} \mathrm{H}$ RMN.

\section{Nuclear Magnetic Resonance ( $\left.{ }^{1} \mathrm{H}-\mathrm{NMR}\right)$ Spectroscopy}

The ${ }^{1} \mathrm{H}$ NMR spectra of F16 fraction were obtained in MercuryVarian spectrometer using $200 \mathrm{MHz}-{ }^{1} \mathrm{H}$. The solvent used was deuterated chloroform $\left(\mathrm{CDCl}_{3}\right)$ whose respective peaks in $\mathrm{RMN}$ ${ }^{1} \mathrm{H}$ were used to adjust the frequency scale.

\section{Antimicrobial Activities}

\section{Microorganisms and Inocula Preparation}

Fifteen microorganisms strains from eleven species (Aspergillus sp., Bacillus subtilis, Candida albicans, Enterococcus faecalis, Escherichia coli, Klebsiella pneumoniae, Micrococcus luteus, Mycobacterium smegmatis, Mycobacterium tuberculosis, Pseudomonas aeruginosa, including clinical isolates of Staphylococcus aureus), obtained from the microorganism collection of the Department of Antibiotics of Federal University of Pernambuco (UFPEDA), were used for the antimicrobial tests, according to Table 1. The bacterial strains were cultured at $37^{\circ} \mathrm{C}$ for 18 hours in Mueller-Hinton Broth and the fungal cultures maintained in Sabouraud Dextrose Agar medium and incubated at $35^{\circ} \mathrm{C}$ for $24 \mathrm{~h}$. As to the preparation of the inoculum, the pricked out strains were transferred to the sterile saline solution $(0.9 \% \mathrm{NaCl})$, composed of a bacterial/fungal suspension (inoculum) until obtaining the concentration of $10^{6} \mathrm{UFC} / \mathrm{mL}$ according to the scale of McFarland. The susceptibility tests were performed by Mueller Hinton agar-well diffusion method (Davis and Stout, 1971; Hombach et al., 2013).

\section{Minimum Inhibitory Concentration (MIC) and Minimal Microbicidal Concentration (MMC) Tests}

The MIC and MMC were determined for plant extracts that showed antimicrobial activity, by a broth microdilution method (Weinstein et al., 2012; Hombach et al., 2013). Briefly, $100 \mu \mathrm{L}$ of Mueller-Hinton Broth plus different concentrations of plant extracts were prepared and transferred to each microplate well to obtain dilutions of the active extract, ranging from 0.001 to $100 \mathrm{mg} / \mathrm{mL}$. Then, $10 \mu \mathrm{L}$ of a fresh culture (final concentration of $1 \times 10^{6} \mathrm{CFU} / \mathrm{mL}$ ) of test organisms was added. Microplates were incubated at $37^{\circ} \mathrm{C}$ for $24 \mathrm{~h}$ and MIC was defined as the lowest concentration of the extract that restricted the visible growth of microorganism tested. To determine MMC, $100 \mu \mathrm{L}$ from each well that showed no visible growth was reinoculated on $\mathrm{MH}$ agar plates; then the plates were incubated at $37^{\circ} \mathrm{C}$ for $24 \mathrm{~h}$. MMC was defined as the lowest extract concentration showing no bacterial growth, DMSO was used as blank.

\section{Antimycobacterial Culture}

The M. smegmatis and M. tuberculosis was maintained on Middlebrook 7H9 broth containing $0.05 \%$ Tween 80 and 10\% (v/v) OADC (Oleic Acid, Albumin, Dextrose, and Catalase) supplement. The culture screening was performed by ZiehlNeelsen staining before used in the antimicrobial assays. Twofold serial dilutions of CLCLE extract and Rifampicin were made with $100 \mu \mathrm{l}$ of each; sterile distilled water and 7H9 Middlebrook culture medium for M. tuberculosis and M. smegmatis in plates of 96 well microplates. The plates were incubated at $37^{\circ} \mathrm{C}$ for 24 days. The developer $(40 \mu \mathrm{L})$ used was iodonitrotetrazolium (INT) of Sigma-Aldrich. Minimum Inhibitory Concentration (MIC) values were recorded as the lowest concentrations of extracts showing no growth, and bacterial growth in the wells was indicated by color change (Damato and Collins, 1990; Sadaphal et al., 2008).

\section{Antimicrobial Activity of C. leptophloeos Hinokinin against Selected MRSA Clinical Isolates}

The study included four $S$. aureus strains obtained from the Department of Antibiotics of Federal University of Pernambuco (UFPEDA). Colonies with macroscopic characteristics of antimicrobial susceptibility patterns from isolates were determined according to Kirby Bauer disk diffusion technique as described by CLSI (Hombach et al., 2013) and Minimum Inhibitory Concentration (MIC). The following three antibiotics were used to determine the antibiogram of the isolates: Tobramycin (10 $\mu \mathrm{g})$, Vancomycin (30 $\mu \mathrm{g})$, and Cefoxitin $(30 \mu \mathrm{g})$. Detection of methicillin resistant S. aureus (MRSA) was carried out using cefoxitin $(30 \mu \mathrm{g})$, an inhibition zone diameter of $\leq 21 \mathrm{~mm}$ was reported as methicillin/oxacillin resistant and $\geq 22 \mathrm{~mm}$ was considered as methicillin/oxacillin sensitive (Hombach et al., 2013; CLSI, 2014; Rabelo et al., 2014). 
TABLE 1 | Microorganisms used in the present study distributed according to groups: bacteria and fungi

\begin{tabular}{lclcc}
\hline Bacteria & UFPEDA & Bacteria & UFPEDA & Fungi \\
\hline Mycobacterium smegmatis & 71 & Staphylococcus aureus & 02 & UFPEDA \\
Mycobacterium tuberculosis & 82 & Staphylococcus aureus & $672^{1}$ & Candida albicans \\
Bacillus subtilis & 86 & Staphylococcus aureus & $677^{1}$ & \\
Micrococcus luteus & 100 & Staphylococcus aureus & $682^{1}$ & \\
Enterococcus faecalis & 138 & Staphylococcus aureus & $728^{1}$ & \\
Escherichia coli & 224 & & & \\
Klebsiella pneumoniae & 396 & & & \\
Pseudomonas aeruginosa & 416 & & & \\
\hline
\end{tabular}

ATCC, American Type Culture Collection. ${ }^{1}$ Infection site of Staphylococcus aureus strains; 672, blood; 677, postoperative secretion; 682, ocular discharge; 728, oropharynx.

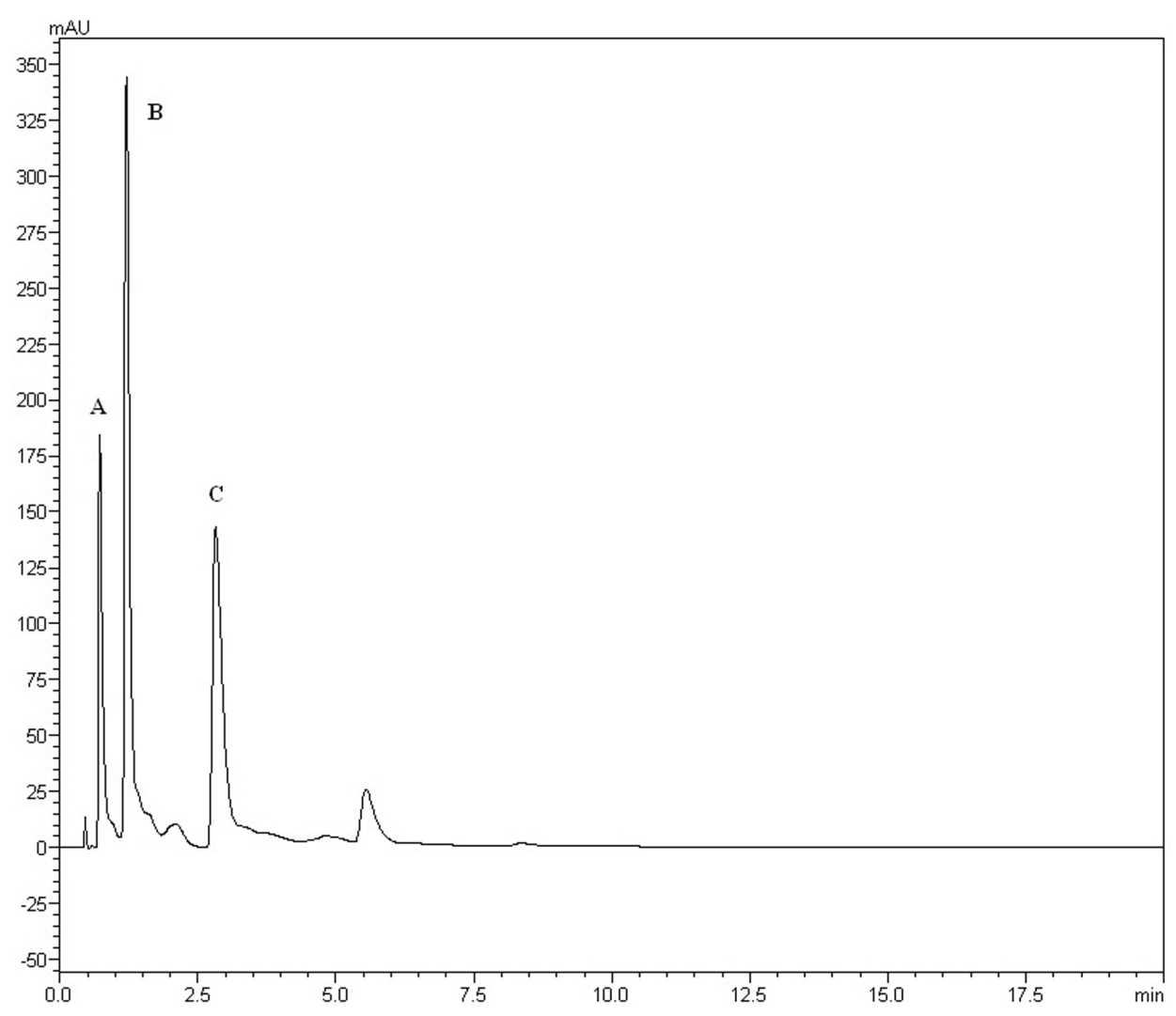

FIGURE 1 | HPLC fingerprints obtained by Chloroform extract (CLECL). The UFLC analysis detected the presence of the bioactive compounds: (A) Gallic acid, (B) Chlorogenic acid, and (C) Protocatechuic acid.

\section{In vitro Hemolytic Assays}

For hemolytic in vitro assay, whole blood $(5 \mathrm{ml})$ was obtained from healthy, non-smoking volunteers by venipuncture, after obtaining written informed consent (National Ethics Committee reference number 30667014.5.0000.5208). Human erythrocytes from citrated blood were immediately isolated by centrifugation at $1500 \mathrm{rpm}$ for $10 \mathrm{~min}$ at $4^{\circ} \mathrm{C}$. After plasma removal, the erythrocytes were washed three times with phosphate-buffered saline (PBS; pH 7.4) and then re-suspended using the same buffer, and a $1 \%$ erythrocyte suspension was prepared. The hemolytic activity of C. leptophloeos extracts was tested under in vitro conditions. Each tube received $1.1 \mathrm{~mL}$ of erythrocyte suspension and $0.4 \mathrm{~mL}$ of extract with different concentrations ranging from 50 to $500 \mu \mathrm{g} / \mathrm{mL}$. The negative control was solvent only and the positive control received $0.4 \mathrm{~mL}$ of Quillaja saponin $(0.0025 \%)$. After $60 \mathrm{~min}$ of incubation at room temperature, cells were centrifuged at $1500 \mathrm{rpm}$ for $10 \mathrm{~min}$ and the supernatant was used to measure the absorbance of the liberated hemoglobin at $540 \mathrm{~nm}$ length. The average value was calculated from triplicate assays (Sulaiman and Gopalakrishnan, 2013). 


\section{Statistical Analysis}

Each experiment was performed in biological duplicates and technical triplicates and results are presented as means and \pm standard deviation (SD). Statistical analysis was performed by Student's $t$-test and ANOVA tests. Differences were considered significant at $p<0.05$. The concentration needed for $50 \%$ inhibition $\left(\mathrm{IC}_{50}\right)$ was estimated graphically by linear regression analysis.

\section{RESULTS}

\section{Phytochemical Analyses of C. leptophloeos}

The yields of the assessed extracts presented values varying between 9.8 and $12.3 \%$, being $9.8 \%$ for CLCHE, $10.2 \%$ for CLECL, $10.5 \%$ for CLAEE, $11.8 \%$ for CLMEE, and $12.3 \%$ for CLAQE. The qualitative phytochemical analysis of C. leptophloeos by HPLC detected the presence of three particular compounds: Gallic acid (GA), Chlorogenic acid (CGA), and Protocatechuic acid (PCA), as showed in Figure 1. The qualitative phytochemical analysis by TLC of C. leptophloeos extracts detected the presence of Phenolic compounds, Flavonoids and Reducing sugars in all extracts (Table 2). The estimation of total phenolic content revealed that CLAQE (33.64 $\pm 0.5 \mathrm{mg}$ of GAE/g) and CLMEE $(20.3 \pm 0.78$ $\mathrm{mg}$ of GAE/g) exhibited the highest phenolic content $(p<0.05)$. The other extracts showed phenolic content values ranging from $13.8 \pm 0.53$ to $12.54 \pm 0.55 \mathrm{mg}$ of GAE/g, showed in Table 2 . The fraction F16 from CLCLE studied shown the presence of hinokinin in our analysis and the spectrum ${ }^{1} \mathrm{H}$ NMR $\left(\mathrm{CDCl}_{3}\right.$, $200 \mathrm{MHz}$ ) of F16 from CLCLE showed two multiplets $(\delta \mathrm{H} 2.45$ e 2.48) in high field, being referent to $\mathrm{sp}^{3}$ hydrogens connected to neighboring carbons of chiral carbon (C-7 and C-7’). In $\delta \mathrm{H} 2.85$ was observed a doublet of doublet $(\mathrm{dd}, J=4.7,14.5 \mathrm{~Hz}, 1 \mathrm{H})$ of 1 $\mathrm{H}$ connected directly to chiral carbon C-8. In $\delta \mathrm{H} 3.00$ the doublet of doublet $(\mathrm{dd}, J=4.7,14.5 \mathrm{~Hz}, 1 \mathrm{H})$ of hydrogen 1 connected directly to the chiral carbon $\left(\mathrm{C}-8^{\prime}\right)$. In $\delta \mathrm{H} 3.85$ (dd, $J=7.0$,
9.2 $\mathrm{Hz}, 1 \mathrm{H})$ and $4.15(\mathrm{dd}, J=6.2,9.0 \mathrm{~Hz}, 1 \mathrm{H})$ two doublets of doublets regarding the hydrogens linked to the carbon C-9. In $\delta \mathrm{H} 5.9471$ a multiplet in $4 \mathrm{H}$ linked to the carbon $\mathrm{C}-10$ and $\mathrm{C}$ 10 ', simultaneously. Finally, a $6 \mathrm{H}$ a multiplet in $\delta \mathrm{H} 6.5$ assigned to aromatic hydrogens were identified. The spectrum elucidation is show in Figure 2. Hinokinin is one of the constituents of secondary metabolites of $C$. leptophloeos described for the first time in this species.

\section{Antimicrobial Screening}

The antibacterial activity of $C$. leptophloeos extracts was recorded against various microorganisms and is presented in Tables 3-5. Overall, all plant extracts exhibit a range of inhibitory potentials with broad spectrum, as they inhibited all bacteria and yeasts species tested. The better antimicrobial results observed were provided by CLMEE, in which MIC ranged from 0.097 to $50.0 \mathrm{mg} / \mathrm{mL}$ ( $p$-value $<0.05$ ) (Tables 3 and 4). CLMEE presented better antimicrobial activities against $\mathrm{Gram}$-positive bacteria with best results for $B$. subtilis (MIC $=3.125 \mathrm{mg} / \mathrm{mL}$ ), E. faecalis $(\mathrm{MIC}=25 \mathrm{mg} / \mathrm{mL})$ and $M$. luteus $(\mathrm{MIC}=0.097 \mathrm{mg} / \mathrm{mL}$ and $\mathrm{MMC}=12.5 \mathrm{mg} / \mathrm{mL}$ ). Against $S$. aureus strain, the best bacteriostatic action was the CLCLE $(\mathrm{MIC}=1.125 \mathrm{mg} / \mathrm{mL})$ and, for this reason, we use F16 fraction purified C. leptophloeos hinokinin to evaluate the action of this lignan against MRSA strains (Table 5). C. leptophloeos also showed antifungal activity, such as Aspergillus sp. (MIC values ranged from 3.125 to $6.25 \mathrm{mg} / \mathrm{mL}$ ) and C. albicans (MIC values ranged from 6.25 to $12.5 \mathrm{mg} / \mathrm{mL}$, $p$-value < 0.05 ) showed in Table 3 . The antimicrobial activities against Gram-negative bacteria were showed in Table 4. CLCHE showed better bacteriostatic effect against $P$. aeruginosa $(\mathrm{MIC}=6.25 \mathrm{mg} / \mathrm{mL}$ ) and $K$. pneumoniae (MIC and $\mathrm{MMC}=\mathrm{MMC} 12.5 \mathrm{mg} / \mathrm{mL})$, CLAEE showed the better activity against $E$. coli (MIC and $\mathrm{MMC}=12.5 \mathrm{mg} / \mathrm{mL}$ ), and CLCLE was tested against Mycobacterium, indicating M. smegmatis (MIC $=12.5 \mathrm{mg} / \mathrm{mL}$ ) to be more susceptible to CLCLE than M. tuberculosis (MIC = $52 \mathrm{mg} / \mathrm{mL}$ ), Table 4 . The MIC values of hinokinin (obtained from the purification

TABLE 2 | Phytochemical analyses of extracts from barks of Commiphora leptophloeos.

\begin{tabular}{|c|c|c|c|}
\hline \multirow{2}{*}{$\begin{array}{l}\text { Commiphora leptophloeos } \\
\text { Extract }\end{array}$} & \multirow{2}{*}{$\begin{array}{l}\text { Phenolic } \\
\text { contents }\end{array}$} & \multicolumn{2}{|c|}{ Phytochemical screen } \\
\hline & & Positive tests for & Negative tests for \\
\hline CLAQE & $33.64 \pm 0.5$ & $\begin{array}{l}\text { Phenolic compounds, Tannins, Flavonoids, and } \\
\text { Reducing sugars. }\end{array}$ & Coumarins, Saponin, Phytosteroids, and Lignans. \\
\hline CLMEE & $20.3 \pm 0.78$ & $\begin{array}{l}\text { Phenolic compounds, Tannins, Coumarins, } \\
\text { Flavonoids, Reducing sugars, and Saponin. }\end{array}$ & Phytosteroids and Lignans. \\
\hline CLCLE & $12.54 \pm 0.55$ & $\begin{array}{l}\text { Phenolic compounds, Tannins, Coumarins, } \\
\text { Flavonoids, Reducing sugars, Phytosteroids, and } \\
\text { Lignans. }\end{array}$ & Saponin \\
\hline CLCHE & $13.8 \pm 0.53$ & $\begin{array}{l}\text { Phenolic compounds, Tannins, Coumarins, } \\
\text { Flavonoids, and Reducing sugars. }\end{array}$ & Saponin, Phytosteroids, and Lignans. \\
\hline CLAEE & $13.7 \pm 0.04$ & $\begin{array}{l}\text { Phenolic compounds, Flavonoids, and Reducing } \\
\text { sugars. }\end{array}$ & Tannins, Coumarins, Saponin, Phytosteroids, and Lignans. \\
\hline
\end{tabular}



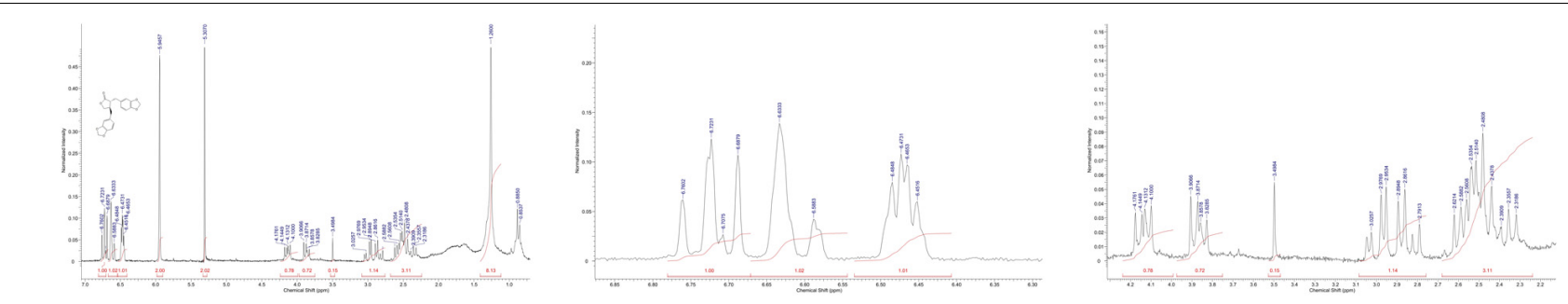

FIGURE $\left.2\right|^{1} \mathrm{H}$ NMR spectra of $\mathrm{F} 16$ fraction $\left(\delta, \mathrm{CDCl}_{3}, 200 \mathrm{MHz}\right)$ of Hinokinin $2 \mathrm{D}$ structure by ACD/I-Lab.

TABLE 3 | Antimicrobial activity of extracts from barks of C. leptophloeos against selected Gram-positive bacteria and fungi.

\begin{tabular}{|c|c|c|c|c|c|c|c|c|c|c|c|c|}
\hline \multirow[t]{2}{*}{$\begin{array}{l}\text { Commiphora } \\
\text { leptophloeos Extract }\end{array}$} & \multicolumn{2}{|c|}{$\begin{array}{l}\text { Bacillus } \\
\text { subtilis }\end{array}$} & \multicolumn{2}{|c|}{$\begin{array}{l}\text { Enterococcus } \\
\text { faecalis }\end{array}$} & \multicolumn{2}{|c|}{$\begin{array}{l}\text { Micrococcus } \\
\text { luteus }\end{array}$} & \multicolumn{2}{|c|}{$\begin{array}{l}\text { Staphylococcus } \\
\text { aureus }\end{array}$} & \multicolumn{2}{|c|}{$\begin{array}{l}\text { Aspergillus } \\
\text { sp. }\end{array}$} & \multicolumn{2}{|c|}{$\begin{array}{l}\text { Candida } \\
\text { albicans }\end{array}$} \\
\hline & MIC & MMC & MIC & MMC & MIC & MMC & MIC & MMC & MIC & MMC & MIC & MMC \\
\hline CLMEE & 3.125 & - & 25 & - & 0.097 & 12.5 & 1.56 & - & 3.15 & - & 6.25 & - \\
\hline CLCLE & 25.0 & - & 25 & - & 0.78 & 25 & 1.125 & - & 6.25 & - & 12.5 & - \\
\hline CLCHE & 12.5 & - & 25 & - & 0.195 & - & 3.125 & - & 6.25 & - & 6.25 & - \\
\hline Control & \multicolumn{2}{|c|}{ MIC } & \multicolumn{2}{|c|}{ MIC } & \multicolumn{2}{|c|}{ MIC } & \multicolumn{2}{|c|}{ MIC } & \multicolumn{2}{|c|}{ MIC } & \multicolumn{2}{|c|}{ MIC } \\
\hline KAN & \multicolumn{2}{|c|}{4} & \multicolumn{2}{|c|}{0.614} & \multicolumn{2}{|c|}{6.8} & \multicolumn{2}{|c|}{1.6} & \multicolumn{2}{|c|}{ N.d. } & \multicolumn{2}{|c|}{3.2} \\
\hline $\mathrm{KCZ}$ & \multicolumn{2}{|c|}{ N.d. } & \multicolumn{2}{|c|}{ N.d. } & \multicolumn{2}{|c|}{ N.d. } & \multicolumn{2}{|c|}{ N.d. } & \multicolumn{2}{|c|}{0.32} & \multicolumn{2}{|c|}{ N.d. } \\
\hline
\end{tabular}

MIC, Minimal Inhibitory Concentration; MMC, Minimal Microbicidal Concentration; MIC and MMC values are expressed in mg/mL. CLAQE, C. leptophloeos aqueous extract; CLMEE, Methanolic extract; CLCLE, Cloroform extract; CLCHE, Cyclohexane extract and CLAEE, Ethyl acetate extract. KAN, Kanamycin and KCZ, Ketoconazole. $N$.d., Not determined. Data were obtained from three independent experiments, each performed in triplicates $(n=3)$ and represented as mean $\pm S D$ and $p$-value $<0.05$.

TABLE 4 | Antimicrobial activity of extracts from barks of $C$. leptophloeos against selected Gram-negative bacteria and Mycobacterium.

\begin{tabular}{|c|c|c|c|c|c|c|c|c|c|c|}
\hline \multirow[t]{2}{*}{ Commiphora leptophloeos Extract } & \multicolumn{2}{|c|}{$\begin{array}{c}\text { Pseudomonas } \\
\text { aeruginosa }\end{array}$} & \multicolumn{2}{|c|}{$\begin{array}{l}\text { Escherichia } \\
\text { coli }\end{array}$} & \multicolumn{2}{|c|}{$\begin{array}{c}\text { Klebsiella } \\
\text { pneumoniae }\end{array}$} & \multicolumn{2}{|c|}{$\begin{array}{l}\text { Mycobacterium } \\
\text { smegmatis }\end{array}$} & \multicolumn{2}{|c|}{$\begin{array}{l}\text { Mycobacterium } \\
\text { tuberculosis }\end{array}$} \\
\hline & MIC & MMC & MIC & MMC & MIC & MMC & MIC & MMC & MIC & MMC \\
\hline CLCLE & 50.0 & - & 12.5 & - & 12.5 & - & 12.5 & - & 54.1 & - \\
\hline CLCHE & 6.25 & - & 12.5 & - & 12.5 & 12.5 & N.d. & N.d. & N.d. & N.d. \\
\hline Control & \multicolumn{2}{|c|}{ MIC } & \multicolumn{2}{|c|}{ MIC } & \multicolumn{2}{|c|}{ MIC } & \multicolumn{2}{|c|}{ MIC } & \multicolumn{2}{|c|}{ MIC } \\
\hline AMP & \multicolumn{2}{|c|}{0.008} & \multicolumn{2}{|c|}{0.004} & \multicolumn{2}{|c|}{0.008} & \multicolumn{2}{|c|}{ N.d. } & \multicolumn{2}{|c|}{ N.d. } \\
\hline RIF & \multicolumn{2}{|c|}{ N.d. } & \multicolumn{2}{|c|}{ N.d. } & \multicolumn{2}{|c|}{ N.d. } & \multicolumn{2}{|c|}{1.16} & \multicolumn{2}{|c|}{2.5} \\
\hline
\end{tabular}

MIC, Minimal Inhibitory Concentration; MMC, Minimal Microbicidal Concentration; MIC and MMC values are expressed in mg/mL. CLAQE, C. leptophloeos aqueous extract; CLMEE, Methanolic extract; CLCLE, Cloroform extract; CLCHE, Cyclohexane extract and CLAEE, Ethyl acetate extract. AMP, Ampicillin and RIF, Rifampicin. N.d., Not determined. Data were obtained from three independent experiments, each performed in triplicates $(n=3)$ and represented as mean $\pm S D$ and $p$-value $<0.05$.

F16 from CLCLE) ranged from 0.0485 to $3.125 \mathrm{mg} / \mathrm{mL}$ ( $p$-value $=0.002)$ for the different $S$. aureus clinical isolates tested, and showed a bactericidal activity against MRSA isolated from blood (MMC $0.40 \mathrm{mg} / \mathrm{mL}$ ) and postoperative secretion $(\mathrm{MMC}=3.125 \mathrm{mg} / \mathrm{mL})$ showed in Table 5 .

\section{In vitro Hemolytic Assays}

The concentration from CLAQE, CLMEE, CLAEE, CLCLEE, and CLCHE extracts demonstrated a $\mathrm{HC}_{50}$ (concentration required for $50 \%$ of hemolysis) of $313 \pm 0.5 \mu \mathrm{g} / \mathrm{mL}$;
$304.9 \mu \mathrm{g} / \mathrm{mL} \pm 0.8 ; 287.49 \mu \mathrm{g} / \mathrm{mL} \pm 3.0 ; 239.5 \mu \mathrm{g} / \mathrm{mL} \pm 1.4$, and $177.21 \mu \mathrm{g} / \mathrm{mL} \pm 0.45$, respectively $(p$-value $=0.001)$.

\section{DISCUSSION}

\section{Phytochemical Analyses of C. leptophloeos}

Species from Commiphora genus present bioactive compounds widely known and used as therapy for several pathologies in 
TABLE 5 | Antimicrobial Activity of C. leptophloeos hinokinin against selected $S$. aureus clinical isolates.

\begin{tabular}{|c|c|c|c|c|c|c|}
\hline \multirow[t]{2}{*}{ UFPEDA } & \multirow[t]{2}{*}{ Source $^{1}$} & \multicolumn{2}{|c|}{ HKN } & \multirow[t]{2}{*}{ VA } & \multirow{2}{*}{\begin{tabular}{|c|} 
TOB \\
IDZ
\end{tabular}} & \multirow[t]{2}{*}{ CFX } \\
\hline & & MIC & MMC & & & \\
\hline 672 & Blood & 0.395 & 0.400 & 11.4 & 13.9 & 14.2 \\
\hline 677 & $\begin{array}{l}\text { Postoperative } \\
\text { secretion }\end{array}$ & 0.0485 & 3.125 & 15.1 & 16 & 14.2 \\
\hline 682 & $\begin{array}{l}\text { Ocular } \\
\text { discharge }\end{array}$ & 3.125 & - & 13.3 & 12 & 15 \\
\hline 728 & Oropharynx & 1.560 & - & 14 & 14.8 & 16 \\
\hline
\end{tabular}

MIC, Minimal Inhibitory Concentration; MMC, Minimal Microbicidal Concentration; MIC and MMC values are expressed in $\mathrm{mg} / \mathrm{mL}$. IDZ Inhibition Disc Zone are expressed in $\mathrm{mm}$ according CLSI. HK, Hinokinin; VA, Vancomycin; TOB, Tobramycin and CFX, Cefoxitin. '1Source of S. aureus strains; 682, ocular discharge; 672, blood; 677, postoperative secretion; 728, oropharynx. Data were obtained from three independent experiments, each performed in triplicates $(n=3)$ and represented as mean $\pm S D$ and $p$-value $<0.05$.

folk culture. Herein, we performed a thorough phytochemical characterization of $C$. leptophloeos, showing its notable amounts of phenolic compounds, namely Gallic acid (GA), Chlorogenic acid (CGA), and Protocatechuic acid (PCA). GA is endowed with pharmacological activities, including antioxidant, antiinflammatory, antimicrobial and antiproliferative activity (Kroes et al., 1992; Vishnu Prasad et al., 2010). On the other hand, CGA has been recently pointed as modulator of glucose and lipid metabolism in vivo, upon unbalanced metabolic conditions such as diabetes (Lou et al., 2011; Sato et al., 2011; Zhao et al., 2012; Hwang et al., 2014). Additionally, PCA, the major metabolite of anthocyanin, provides beneficial activities to human's health such as reduced risk of cardiovascular diseases (Wang et al., 2010), anti-inflammatory, antioxidant and free radical scavenging activities (Li, 2011), as well as estrogenic and antiestrogenic activity (Kakkar and Bais, 2014).

Our phytochemical characterization showed the presence of other bioactive compounds in C. leptophloeos, such as hinokinin, an important class of lignans, which has been recently investigated in order to establish its biological activities (REFERENCIA). Lignans are important components of food and medicines biosynthetically deriving from the radical coupling of two molecules of coniferyl alcohol at C-8/C-8' positions. In the past years, the biological activities of several lignans have been studied in depth (Aehle et al., 2011; Zhang et al., 2014) and among them, the hinokinin (Figure 2) is emerging as a new interesting compound with pharmacological potential. Hinokinin was isolated for the first time in 1933 by Yoshiki and Ishiguro from an ether extract of Hinoki wood - Chamaecyparis obtuse - as a colorless crystalline compound and over the years it has been gradually characterized and described by other researchers (Vanoeveren et al., 1994; Timple et al., 2013; Desai et al., 2014).

\section{Antimicrobial Screening}

Commiphora leptophloeos shows antibacterial activity against several human Gram-positive pathogens such as B. subtilis, E. faecalis, M. luteus, and S. aureus (Table 3). The inhibition of bacterial growth in vitro by the extracts of $C$. leptophloeos could be due to the presence of some active compounds including flavonoids, phenolic acids and tannins, described in Table 2, known to be effective antimicrobial agents against a wide array of microorganisms. These active compounds may act alone or in combination to inhibit bacterial growth. Our results against $M$. luteus strain showed a MIC ranging from 0.097 to $12.5 \mathrm{mg} / \mathrm{mL}$, and the CLMEE as the extract showing the best bacteriostatic and bactericidal action $(\mathrm{MMC}=12.5 \mathrm{mg} / \mathrm{mL})$, particularly when compared to other studies with Commiphora genus (Latha et al., 2005) and when compared with the MIC value obtained by the aminoglycoside Kanamycin (MIC $=6.8 \mathrm{mg} / \mathrm{mL})$. M. luteus is a natural constituent of mammalian skin microflora and considered a nosocomial contaminant mainly in immunodeficient individuals, causing meningitis (Fosse et al., 1985) and endocarditis (Miltiadous and Elisaf, 2011) in severe infections. Immunodeficiency is a risk factor able to intensify selection and dissemination of multidrug resistance strains. C. leptophloeos extracts are also effective against Aspergillus sp. and C. albicans, the most prevalent fungal species of the human microbiota, often associated to several complications in immunosuppressed individuals (Nobile and Johnson, 2015).

Gram-negative pathogens are particularly alarming, due to their resistance to nearly all drugs firstly considered for treatment. The reason for this relies on their several pathways to $\beta$-lactam resistance through $\beta$-lactamases enzymes production, therefore interfering with the mechanism of action of $\beta$-lactam antibiotics. The same premise has become more frequent in Gram-positive infections (e.g., Staphylococcus). P. aeruginosa is a ubiquitous opportunistic pathogen, having outer membrane cell structure conferring pronounced resistance to xenobiotics (Gaspar et al., 2013). Previous studies had already reported the action of the aqueous extract of C. leptophloeos inhibition of biofilms of $P$. aeruginosa (Trentin et al., 2013) and S. epidermidis (Trentin et al., 2011). According to these aforementioned studies, CLCHE presented ample bacteriostatic activity against $P$. aeruginosa, with MIC of $6.25 \mathrm{mg} / \mathrm{mL}$ (Table 4), this greater potential of action is due the presence of tannins in CLCHE, as noted in our phytochemical profile (Table 2). E. coli is a bacterium usually found in intestinal microflora, nevertheless, some can cause debilitating and sometimes fatal human diseases (Riley, 2014). Pathogenic strains are divided into intestinal pathogens causing diarrhea and extraintestinal mainly related to urinary tract infections pyelonephritis, cystitis, and urosepsis (Croxen et al., 2013). Only two fractions, CLCHE and the CLMEE, showed bactericidal action (MMC ranging 12.5 to $25 \mathrm{mg} / \mathrm{mL}$ ), suggesting that this action may be due to the presence of high amounts of phenolic acids (Figure 1), such as GA, which might contribute to the inhibition E. coli strain.

Klebsiella pneumoniae is a type of Gram-negative bacteria that may cause different types of infections including pneumonia, meningitis, bloodstream infections. Generation of extendedspectrum $\beta$ - lactamases is one of the major mechanisms by which clinical K. pneumoniae develop resistance to antibiotics (Cai et al., 2016). Herein we identified that the CLCHE and CLAEE fractions effectively act as antibacterial agent in 
the Gram-negative tested strains (Table 4). The antibacterial activities of $C$. leptophloeos extracts were also detected against M. smegmatis and M. tuberculosis strains as showed in Table 4. A bacteriostatic effect against Mycobacterium species by plants secondary metabolites may be due to pathogen's thick outer membrane that is highly hydrophobic and possibly provided a permeability to the extract (Yamori et al., 1992; Firmani and Riley, 2002).

Oxacillin and methicillin resistant $S$. aureus (MRSA) are resistant to all $\beta$-lactam agents including cephalosporin's and carbapenems, causing global commitment in stopping its spread responsible for approximately $40 \%$ of $S$. aureus infections in global Intensive Care Units (ICU) (Frieden, 2013; Cuny et al., 2015). In our study, were evaluated four MRSA clinical isolated strains reported as Methicillin Resistance (Oxacillin Resistance) confirmed with CFX inhibition disc tests at where cefoxitin is used as a surrogate for mecA-mediated oxacillin resistance (CLSI, 2014). C. leptophloeos hinokinin showed the highest antibacterial activity against MRSA isolated of blood, with a bacteriostatic activity (MIC) of $0.39 \mathrm{mg} / \mathrm{mL}$ and bactericidal (MMC) of $0.40 \mathrm{mg} / \mathrm{mL}$, both with very similar values (Table 5). Our results point towards a promising antimicrobial potential against S. aureus resistant, especially when compared to others studies (Saeed and Sabir, 2004; Abdallah et al., 2009; Abdulgader et al., 2015), once we obtained more pronounced antibacterial results, corroborating the antimicrobial potential of hinokinin.

Regarding hemolytic activity of C. leptophloeos extracts, the values obtained for hemolysis were superior to the ones regarding its antimicrobial activity, showing its safety. Even though a phytochemical study on another Commiphora genus (Hanus et al., 2005) has shown the presence of possibly toxic compounds, the toxicity assay performed in vitro for Amburana hemolytic properties did not show the same results. Regardless, we recognize the importance of applying other methods to assess toxicity from these extracts over other cellular components. Hemolytic assays were performed to assess cell safety in future pharmacological preparations without causing any harm. In the present study our trials with Commiphora showed lower hemolytic activity when comparing to other

\section{REFERENCES}

Abdallah, E. M., Khalid, A. S., and Ibrahim, N. (2009). Antibacterial activity of oleogum resins of Commiphora molmol and Boswellia papyrifera against methicillin resistant Staphylococcus aureus (MRSA). Sci. Res. Essay 4, 351-356.

Abdel-Daim, M. M., Ghazy, E. W., and Fayez, M. (2015). Synergistic protective role of mirazid (Commiphora molmol) and ascorbic acid against tilmicosininduced cardiotoxicity in mice. Can. J. Physiol. Pharmacol. 93, 45-51. doi: 10.1139/cjpp-2014-0336

Abdulgader, S. M., Shittu, A. O., Nicol, M. P., and Kaba, M. (2015). Molecular epidemiology of Methicillin-resistant Staphylococcus aureus in Africa: a systematic review. Front. Microbiol. 6:348. doi: 10.3389/fmicb.2015.00348

Aehle, E., Müller, U., Eklund, P. C., Willför, S. M., Sippl, W., and Dräger, B. (2011). Lignans as food constituents with estrogen and antiestrogen activity. Phytochemistry 72, 2396-2405. doi: 10.1016/j.phytochem.2011.08.013

Bennett, B. C., and Prance, G. T. (2000). Introduced plants in the indigenous pharmacopoeia of Northern South America 1. Econ. Bot. 1, 90-102. doi: 10. 1007/BF02866603 species from the Caatinga biome (Silva et al., 2011; Tam et al., 2015).

\section{CONCLUSION}

In the present study, we identified that the bark extracts from C. leptophloeos contain an important amount of phenolic compounds, such as GA, PCA, and CGA. Furthermore, we have identified for the first time the presence of hinokinin in Commiphora genus. Our results showed that C. leptophloeos presents potential inhibitory properties against $S$. aureus multidrugs resistance species, as well as several Gram-positives, Gramnegatives and fungi, and should also be studied for their potential against Mycobacterium.

\section{AUTHOR CONTRIBUTIONS}

JdS, performed plant collection, biochemical and antimicrobial assays, analysis and wrote the paper; AdP, performed plant collection and participated in all biochemical and microorganism's assays; JJ, performed the collection and all microorganisms' assays; JdP, performed chemical assays and analysis; SC, discussed the results and helped in its delimitation from for the final manuscript; MdS, Coordinated the project, participated in plant collection, during all biochemical assays, chemical analysis, and in manuscript writing; JdA, Coordinated the project including all plant collection, biochemical, chemical, and biological assays and discussed all results.

\section{FUNDING}

This work was supported by the following Brazilian funding agencies: CAPES (Coordenação de Aperfeiçoamento de Pessoal de Nível Superior), CNPq (Conselho Nacional de Desenvolvimento Científico e Tecnológico), and FACEPE (Fundação de Amparo à Ciência e Tecnologia de Pernambuco).

Bhalodia, N. R., Nariya, P. B., and Shukla, V. J. (2011). Antibacterial and antifungal activity from flower extracts of Cassia fistula L.: An ethnomedicinal plant. Int. J. Pharm. Tech. Res. 3, 160-168. doi: 10.1016/j.jep.2007.04.008

Bhatter, P., Gupta, P., Daswani, P., Tetali, P., and Birdi, T. (2015). Antimycobacterial efficacy of Andrographis paniculata leaf extracts under intracellular and hypoxic conditions. J Evid Based Complement. Altern. Med. 20, 3-8. doi: 10.1177/2156587214553303

Bhatter, P. D., Gupta, P. D., and Birdi, T. J. (2016). Activity of medicinal plant extracts on multiplication of Mycobacterium tuberculosis under reduced oxygen conditions using intracellular and axenic assays. Int. J. Microbiol. 2016, 1-6. doi: $10.1155 / 2016 / 8073079$

Cai, W., Fu, Y., Zhang, W., Chen, X., Zhao, J., Song, W., et al. (2016). Synergistic effects of baicalein with cefotaxime against Klebsiella pneumoniae through inhibiting CTX-M-1 gene expression. BMC Microbiol. 16:181. doi: 10.1186/ s12866-016-0797-1

Clark, W., Still, W. C., Kahn, M., and Mitra, A. (1978). Rapid chromatographic technique for preparative separations with moderate resolution. J. Org. Chem. 43, 2923-2925. doi: 10.1021/jo00408a041 
CLSI (2014). Performance standards for antimicrobial susceptibility testing; twenty-fourth informational supplement. Clin. Lab. Stand. Inst. 34, M100M123.

Croxen, M. A., Law, R. J., Scholz, R., Keeney, K. M., Wlodarska, M., and Finlay, B. B. (2013). Recent advances in understanding enteric pathogenic Escherichia coli. Clin. Microbiol. Rev. 26, 822-880. doi: 10.1128/CMR.00022-13

Cuny, C., Wieler, L., and Witte, W. (2015). Livestock-associated MRSA: the impact on humans. Antibiotics 4, 521-543. doi: 10.3390/antibiotics4040521

Damato, J. J., and Collins, M. T. (1990). Growth of Mycobacterium paratuberculosis in radiometric, middlebrook and egg-based media. Vet. Microbiol. 22, 31-42. doi: 10.1016/0378-1135(90)90122-C

Davis, W. W., and Stout, T. R. (1971). Disc plate method of microbiological antibiotic assay. I. Factors influencing variability and error. Appl. Microbiol. 22, 659-665.

Desai, D. C., Jacob, J., Almeida, A., Kshirsagar, R., and Manju, S. L. (2014). Isolation, structural elucidation and anti-inflammatory activity of astragalin, (-)hinokinin, aristolactam I and aristolochic acids (I \& II) from Aristolochia indica. Nat. Prod. Res. 28, 1413-1417. doi: 10.1080/14786419.2014.905563

Fernandes, A., Sousa, A., Mateus, N., Cabral, M., and de Freitas, V. (2011). Analysis of phenolic compounds in cork from Quercus suber L. by HPLC-DAD/ESI-MS. Food Chem. 125, 1398-1405. doi: 10.1016/j.foodchem.2010.10.016

Firmani, M. A., and Riley, L. W. (2002). Reactive nitrogen intermediates have a bacteriostatic effect on Mycobacterium tuberculosis in vitro. J. Clin. Microbiol. 40, 3162-3166. doi: 10.1128/JCM.40.9.3162-3166.2002

Fosse, T., Toga, B., Peloux, Y., Granthil, C., Bertrando, J., and Sethian, M. (1985). Meningitis due to Micrococcus luteus. Infection 13, 280-281. doi: 10.1007/ BF01645439

Frieden, T. (2013). Antibiotic Resistance Threats in the United States. Atlanta, GA: Centers for Disease Control and Prevention, 114.

Garcia, S., Heinzen, H., Martinez, R., and Moyna, P. (1993). Identification of flavonoids by TLC scanning analysis. Chromatographia 35, 430-434. doi: 10. 1007/BF02278597

Gaspar, M. C., Couet, W., Olivier, J.-C., Pais, A. A. C. C., and Sousa, J. J. S. (2013). Pseudomonas aeruginosa infection in cystic fibrosis lung disease and new perspectives of treatment: a review. Eur. J. Clin. Microbiol. Infect. Dis. 32, 1231-1252. doi: 10.1007/s10096-013-1876-y

Gocan, S., and Cimpan, G. (2007). Review of the analysis of medicinal plants by TLC?: modern approaches. J. Liq. Chromatogr. Relat. Technol. Publ. 27, 37-41. doi: 10.1081/JLC-120030607

Gómez-Caravaca, A. M., Verardo, V., Toselli, M., Segura-Carretero, A., FernándezGutiérrez, A., and Caboni, M. F. (2013). Determination of the major phenolic compounds in pomegranate juices by HPLC-DAD-ESI-MS. J. Agric. Food Chem. 61, 5328-5337. doi: 10.1021/jf400684n

Hanus, L. O., Rezanka, T., Dembitsky, V. M., and Moussaieff, A. (2005). Myrrh Commiphora chemistry. Biomed. Pap. Med. Fac. Univ. Palacky. Olomouc. Czech. Repub. 149, 3-27. doi: 10.5507/bp.2005.001

Harborne, J. B. (1997). "Plant secondary metabolism," in Plant Ecology, 2nd Edn, ed. M. J. Crawley (Oxford: Blackwell Publishing Ltd), 132-155. doi: 10.1002/ 9781444313642.ch5

Heleno, S. A., Martins, A., Queiroz, M. J. R. P., and Ferreira, I. C. F. R. (2015). Bioactivity of phenolic acids: metabolites versus parent compounds: a review. Food Chem. 173, 501-513. doi: 10.1016/j.foodchem.2014.10.057

Hombach, M., Mouttet, B., and Bloemberg, G. V. (2013). Consequences of revised CLSI and EUCAST guidelines for antibiotic susceptibility patterns of ESBL- and AmpC $\beta$-lactamase-producing clinical Enterobacteriaceae isolates. J. Antimicrob. Chemother. 68, 2092-2098. doi: 10.1093/jac/dkt135

Hwang, S. J., Kim, Y.-W., Park, Y., Lee, H.-J., and Kim, K.-W. (2014). Antiinflammatory effects of chlorogenic acid in lipopolysaccharide-stimulated RAW 264.7 cells. Inflamm. Res. 63, 81-90. doi: 10.1007/s00011-013-0674-4

Kakkar, S., and Bais, S. (2014). A review on protocatechuic acid and its pharmacological potential. ISRN Pharmacol. 2014:952943. doi: 10.1155/2014/ 952943

Krishnamurthy, P., Tsukamoto, C., Yang, S. H., Lee, J. D., and Chung, G. (2012). An improved method to resolve plant saponins and sugars by TLC. Chromatographia 75, 1445-1449. doi: 10.1007/s10337-012-2340-3

Kroes, B. H., van den Berg, A. J., Quarles van Ufford, H. C., van Dijk, H., and Labadie, R. P. (1992). Anti-inflammatory activity of gallic acid. Planta Med. 58, 499-504. doi: 10.1055/s-2006-961535
Kroymann, J. (2011). Natural diversity and adaptation in plant secondary metabolism. Curr. Opin. Plant Biol. 14, 246-251. doi: 10.1016/j.pbi.2011.03.021

Latha, S., Selvamani, P., Sen, D. J., Gupta, J. K., Pal, T. K., and Ghosh, L. K. (2005). Antibacterial activity of Commiphora caudata and Commiphora berryi leaves. Indian Drugs 42, 696-698.

Lawn, S. D., Zumla, A. I., Raviglione, M., Hafner, R., and von Reyn, C. F. (2013). Tuberculosis. Lancet 378, 57-72. doi: 10.1056/NEJMra1200894

Li, X. (2011). Antioxidant activity and mechanism of protocatechuic acid in vitro. Funct. Foods Heal. Dis. 7, 232-244.

Lou, Z., Wang, H., Zhu, S., Ma, C., and Wang, Z. (2011). Antibacterial activity and mechanism of action of chlorogenic acid. J. Food Sci. 76, M398-M403. doi: 10.1111/j.1750-3841.2011.02213.x

Miltiadous, G., and Elisaf, M. (2011). Native valve endocarditis due to Micrococcus luteus: a case report and review of the literature. J. Med. Case Rep. 5: 251. doi: 10.1186/1752-1947-5-251

Ng, K. G., Price, K. R., and Fenwick, G. R. (1994). A TLC method for the analysis of quinoa (Chenopodium quinoa) saponins. Food Chem. 49, 311-315. doi: 10. 1016/0308-8146(94)90177-5

Nobile, C. J., and Johnson, A. D. (2015). Candida albicans biofilms and human disease. Annu. Rev. Microbiol. 69, 71-92. doi: 10.1146/annurev-micro-091014104330

Pascual, M. E., Carretero, M. E., Slowing, K. V., and Villar, A. (2008). Simplified screening by TLC of plant drugs. Pharm. Biol. 40, 139-143. doi: 10.1076/phbi. 40.2.139.5849

Peña-Claros, M., Poorter, L., Alarcn, A., Blate, G., Choque, U., Fredericksen, T. S., et al. (2012). Soil effects on forest structure and diversity in a moist and a dry tropical forest. Biotropica 44, 276-283. doi: 10.1111/j.1744-7429.2011. 00813.x

Prieto, P., Pineda, M., and Aguilar, M. (1999). Spectrophotometric quantitation of antioxidant capacity through the formation of a phosphomolybdenum complex: specific application to the determination of vitamin E. Anal. Biochem. 269, 337-341. doi: 10.1006/abio.1999.4019

Rabelo, M. A., Neto, A. M. B., Loibman, S. O., da Costa Lima, J. L., Ferreira, E. L., Leal, N. C., et al. (2014). The occurrence and dissemination of methicillin and vancomycin-resistant Staphylococcus in samples from patients and health professionals of a university hospital in recife, State of Pernambuco, Brazil. Rev. Soc. Bras. Med. Trop. 47, 437-446. doi: 10.1590/0037-8682-0071-2014

Riley, L. W. (2014). Pandemic lineages of extraintestinal pathogenic Escherichia coli. Clin. Microbiol. Infect. 20, 380-390. doi: 10.1111/1469-0691.12646

Sadaphal, P., Rao, J., Comstock, G. W., and Beg, M. F. (2008). Image processing techniques for identifying Mycobacterium tuberculosis in Ziehl-Neelsen stains. Int. J. Tuberc. Lung Dis. 12, 579-582.

Saeed, M. A., and Sabir, A. W. (2004). Antibacterial activities of some constituents from oleo-gum-resin of Commiphora mukul. Fitoterapia 75, 204-208. doi: 10. 1016/j.fitote.2003.12.003

Sato, Y., Itagaki, S., Kurokawa, T., Ogura, J., Kobayashi, M., Hirano, T., et al. (2011). In vitro and in vivo antioxidant properties of chlorogenic acid and caffeic acid. Int. J. Pharm. 403, 136-138. doi: 10.1016/j.ijpharm.2010.09.035

Silva, M. I. G., de Melo, C. T. V., Vasconcelos, L. F., de Carvalho, A. M. R., and Sousa, F. C. F. (2011). Bioactivity and potential therapeutic benefits of some medicinal plants from the Caatinga (semi-arid) vegetation of Northeast Brazil: a review of the literature. Rev. Bras. Farmacogn. 22, 193-207. doi: 10.1590/S0102695X2011005000171

Singleton, V. L., Rossi, J. A. Jr., and Rossi, J. A. Jr. (1965). Colorimetry of total phenolics with phosphomolybdic-phosphotungstic acid reagents. Am. J. Enol. Vitic. 16, 144-158. doi: 10.12691/ijebb-2-1-5

Still, C. (2002). Flash chromatography. Mater. Today 5:42. doi: 10.1016/S13697021(02)01160-4

Sulaiman, C. T., and Gopalakrishnan, V. K. (2013). Radical scavenging and in-vitro hemolytic activity of aqueous extracts of selected acacia species. J. Appl. Pharm. Sci. 3, 109-111. doi: 10.7324/JAPS.2013.30321

Tam, J. P., Wang, S., Wong, K. H., and Tan, W. L. (2015). Antimicrobial peptides from plants. Pharmaceuticals 8, 711-757. doi: 10.3390/ph8040711

Teponno, R. B., Kusari, S., and Spiteller, M. (2016). Recent advances in research on lignans and neolignans. Nat. Prod. Rep. 33, 1044-1092. doi: 10.1039/ C6NP00021E

Timple, J. M. V., Magalhães, L. G., Souza Rezende, K. C., Pereira, A. C., Cunha, W. R., Andrade e Silva, M. L., et al. (2013). The lignan (-)-hinokinin displays 
modulatory effects on human monoamine and gaba transporter activities. J. Nat. Prod. 76, 1889-1895. doi: 10.1021/np400452n

Trentin, D. D. S., Giordani, R. B., Zimmer, K. R., Da Silva, A. G., Da Silva, M. V., Correia, M. T. D. S., et al. (2011). Potential of medicinal plants from the Brazilian semi-arid region (Caatinga) against Staphylococcus epidermidis planktonic and biofilm lifestyles. J. Ethnopharmacol. 137, 327-335. doi: 10.1016/ j.jep.2011.05.030

Trentin, D. S., Silva, D. B., Amaral, M. W., Zimmer, K. R., Silva, M. V., Lopes, N. P., et al. (2013). Tannins possessing bacteriostatic effect impair Pseudomonas aeruginosa adhesion and biofilm formation. PLoS ONE 8:e66257. doi: 10.1371/ journal.pone.0066257

Vanoeveren, A., Jansen, J., and Feringa, B. L. (1994). Enantioselective synthesis of natural dibenzylbutyrolactone lignans (-)-enterolactone, (-)-hinokinin, (-)-pluviatolide, (-)-enterodiol, and furofuran lignan (-)-eudesmin via tandem conjugate addition to gamma-alkoxybutenolides. J. Org. Chem. 59, 5999-6007. doi: 10.1021/jo00099a033

Venturini, E., Turkova, A., Chiappini, E., Galli, L., de Martino, M., and Thorne, C. (2014). Tuberculosis and HIV co-infection in children. BMC Infect. Dis. 14(Suppl. 1):S5. doi: 10.1186/1471-2334-14-S1-S5

Vishnu Prasad, C. N., Anjana, T., Banerji, A., and Gopalakrishnapillai, A. (2010). Gallic acid induces GLUT4 translocation and glucose uptake activity in 3T3-L1 cells. FEBS Lett. 584, 531-536. doi: 10.1016/j.febslet.2009.11.092

Wang, D., Wei, X., Yan, X., Jin, T., and Ling, W. (2010). Protocatechuic acid, a metabolite of anthocyanins, inhibits monocyte adhesion and reduces atherosclerosis in apolipoprotein E-deficient mice. J. Agric. Food Chem. 58, 12722-12728. doi: 10.1021/jf103427j

Weinstein, M. P., Zimmer, B. L., Cockerill, F. R., Wikler, M. A., Alder, J., Dudley, M. N., et al. (2012). Methods for Dilution Antimicrobial Susceptibility Tests for Bacteria That Grow Aerobically, Approved Standard - 9th Edn. Wayne, PA:Clinical and Laboratory Standards Institute.

WHO (2015). WHO | Tuberculosis and HIV. Geneva: World Health Organization.

Yamori, S., Ichiyama, S., Shimokata, K., and Tsukamura, M. (1992). Bacteriostatic and bactericidal activity of antituberculosis drugs against Mycobacterium tuberculosis, Mycobacterium avium-Mycobacterium intracellulare complex and Mycobacterium kansasii in different growth phases. Microbiol. Immunol. 36, 361-368. doi: 10.1111/j.1348-0421.1992.tb02035.x

Zhang, J., Chen, J., Liang, Z., and Zhao, C. (2014). New lignans and their biological activities. Chem. Biodivers. 11, 1-54. doi: 10.1002/cbdv.2011 00433

Zhao, Y., Wang, J., Ballevre, O., Luo, H., and Zhang, W. (2012). Antihypertensive effects and mechanisms of chlorogenic acids. Hypertens. Res. 35, 370-374. doi: 10.1038/hr.2011.195

Zumla, A., Raviglione, M., Hafner, R., and von Reyn, C. F. (2013). Tuberculosis. N. Engl. J. Med. 368, 745-755. doi: 10.1056/NEJMra1200894

Conflict of Interest Statement: The authors declare that the research was conducted in the absence of any commercial or financial relationships that could be construed as a potential conflict of interest.

Copyright (C) 2017 de Souza Pereira, Pereira, Jandú, da Paz, Crovella, dos Santos Correia and de Azevêdo Silva. This is an open-access article distributed under the terms of the Creative Commons Attribution License (CC BY). The use, distribution or reproduction in other forums is permitted, provided the original author (s) or licensor are credited and that the original publication in this journal is cited, in accordance with accepted academic practice. No use, distribution or reproduction is permitted which does not comply with these terms. 